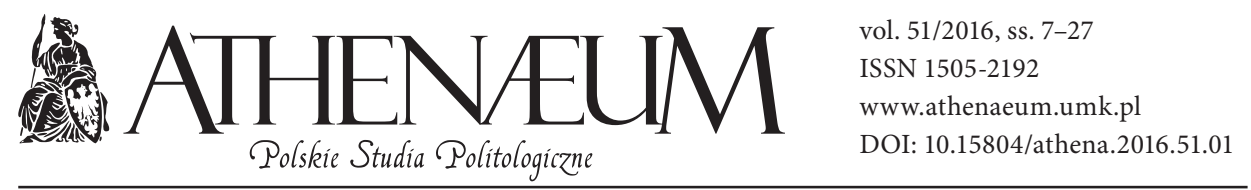

\title{
METODY PORÓWNAWCZE STOSOWANE W BADANIACH SYSTEMÓW WYBORCZYCH
}

\author{
THE USE OF COMPARATIVE METHODS IN THE STUDY \\ OF ELECTORAL SYSTEMS
}

Bartłomiej Michalak*

\begin{abstract}
ABSTRAKT
$\mathrm{W}$ ostatnich latach w nauce o polityce coraz więcej uwagi poświęca się kwestiom metodologicznym, nie bez racji przypominając, że o tożsamości i dojrzałości dyscypliny świadczą metody, $z$ jakich ona korzysta. Tymczasem badanie konsekwencji systemów wyborczych bardzo dobrze poddaje się kwantyfikacji. „Twarde” dane wyborcze (takie jak liczba głosów, mandatów, partii i kandydatów) już na wejściu doskonale nadają się do analiz ilościowych, co dla empirycznie zorientowanej politologii stanowi niebywałą wartość. Co więcej, ponad 60 lat badań w tym obszarze zaowocowało wytworzeniem wielu technik i narzędzi przetwarzania oraz sposobów interpretowania tych danych. Warsztat ten cały czas podlega ewaluacji i ewolucji. Celem tego artykułu będzie krytyczne omówienie najważniejszych podejść metodologicznych i metod badawczych stosowanych do tej pory przy analizach konsekwencji systemów wyborczych. Są one tak różne zarówno pod względem swoich założeń wyjściowych, procedury badawczej oraz sposobu interpretacji wyników, że wydaje się wręcz konieczne ich
\end{abstract}

In recent years, much attention has been paid to methodological issues within the purview of political science, what rightly reminds us that the identity and maturity of a scientific discipline is revealed in the methods employed by it. At the same time, the examination of the electoral systems' consequences is easily submitted for quantification. The 'hard' election data such as the number of votes and seats as well as the number of political parties and candidates are excellent materials for quantitative analysis, what is of the great value for the empirically oriented political science. Moreover, more than 60 years of research in this field have resulted in the development of various methods, techniques, tools and interpretative approaches towards aforementioned data. These methodological achievements continuously undergo the process of evaluation and evolution. The aim of this paper is to present and discuss, in a critical way, the most important research methods and methodological approaches that have until now been used to study the consequences of electoral systems. These methods and

* Uniwersytet Mikołaja Kopernika w Toruniu, Wydział Politologii i Studiów Międzynarodowych. 
wyodrębnienie jako osobnych metod porównawczych.

Słowa kluczowe: komparatystyka, metoda porównawcza, systemy wyborcze, metoda instytucjonalna-prawna, metoda historyczno-empiryczna, metoda statystyczno-empiryczna, metoda logiczno-empiryczna methodological approaches vary so much as far as their starting assumptions, techniques of collecting data and ways of interpreting the results are concerned, that it seems almost necessary to treat them as separate comparative methods.

Keywords: comparative method, electoral systems, institutional method, historical-empirical method, statistical-empirical method, quantitatively predictive logical models

W ostatnich latach w nauce o polityce coraz więcej uwagi poświęca się kwestiom metodologicznym, nie bez racji podnosząc, że o tożsamości dyscypliny świadczy m.in. stopień dojrzałości metod, $\mathrm{z}$ jakich ona korzysta. Tymczasem studia nad systemami wyborczymi należą do grona najbardziej rozwiniętych na gruncie nauk politycznych. Rein Taagepera i Matthew Soberg Shugart (1989, s. 5), klasycy ilościowych badań porównawczych w politologii, już dawno zauważyli, że w porównaniu $\mathrm{z}$ innymi politycznymi fenomenami systemy wyborcze operujące wieloma "twardymi” danymi liczbowymi doskonale nadają się do badania przy wykorzystaniu technik stosowanych w bardziej zaawansowanych metodologicznie dyscyplinach naukowych. Ich zdaniem głosy wyborców mogłyby stać się, dla ilościowego zorientowanych nauk politycznych tym, czym masa stała się dla fizyki, a pieniądze dla ekonomii: najlepszą podstawową wartością mierzalną. Nie tylko takie łatwo definiowalne i mierzalne wartości, jak głosy i mandaty, ale także nieco bardziej skomplikowane w konceptualizacji pojęcia, jak np. liczba relewantnych (istotnych) partii politycznych, dadzą się bowiem precyzyjnie skwantyfikować. W tym sensie ilościowo zorientowane badania systemów wyborczych mogą stać się swoistym politologicznym kamieniem z Rosetty ${ }^{1}$, wzorcem postępowania badawczego dla innych subdyscyplin całej dziedziny.

Celem tego artykułu będzie zaprezentowanie najważniejszych metod i podejść badawczych stosowanych do tej pory na polu badań nad mechanizmami i konsekwencjami systemów wyborczych, a w dalszej kolejności znalezienie wspólnego rdzenia metodologicznego dla tych podejść. Podane zostaną również przykłady

\footnotetext{
${ }^{1}$ Kamień z Rosetty został wykopany w 1799 r. w Egipcie. Dzięki temu, że zawierał tę samą treść zapisaną w kilku wersjach językowych, umożliwił znalezienie kodu do zrozumienia egipskich hieroglifów.
} 
najbardziej charakterystycznych badań. W artykule dokonana zostanie również ewaluacja poszczególnych podejść badawczych z punku widzenia ich metodologicznej poprawności i eksplanacyjnej przydatności.

\section{KOMPARATYSTYKA SYSTEMÓW WYBORCZYCH}

Jedną z podstawowych metod badawczych współczesnej politologii, a więc również systemów wyborczych, jest metoda porównawcza zwana też komparatystyczną. Zdaniem Arenda Lijpharta (1971, s.682-683) jest to jedna z głównych metod - obok metody eksperymentalnej, statystycznej i studium przypadku - charakteryzująca stabilne nauki empiryczne. W tym ujęciu jest to metoda o szerokim zakresie stosowania, umożliwiająca odkrywanie empirycznych relacji pomiędzy zmiennymi, a nie wąsko rozumiana technika ich pomiaru. W swej istocie sprowadza się do zidentyfikowania podobieństw i/lub różnic w stosunku do co najmniej dwóch obiektów reprezentujących określoną klasę zjawisk politycznych. Wyjaśnienia porównawcze na jej gruncie przybierają różne formy. Do najczęściej wykorzystywanych należą te, które odwołują się do jednej z technik analizy nazywanej metodą zgody lub różnicy. W pierwszym przypadku dyrektywa badawcza nakazuje znaleźć dwa lub więcej państw, które są do siebie podobne pod wszystkimi względami z wyjątkiem zmiennych, których wzajemny wpływ interesuje badacza. W drugim podejściu należy znaleźć dwa lub więcej państw, które różnią się pod wszystkimi możliwymi względami z wyjątkiem analizowanych zmiennych (Hopkin, 2006, s. 254-255).

Aplikacja powyższych dyrektyw na polu badań systemów wyborczych może wyglądać następująco:

1. jeśli można znaleźć przynajmniej dwa państwa, które nie różnią się co do istoty pod względem ustroju politycznego, kultury politycznej, liczby i charakteru podziałów socjopolitycznych, wielkości populacji itd., a różnią się np. tylko pod względem formatu systemu partyjnego (dwupartyjny vs. wielopartyjny) i typu systemu wyborczego (większościowy vs. proporcjonalny), to znając naturę obydwu systemów, można wyciągnąć wniosek, że systemy większościowe determinują format dwupartyjny (a przynajmniej z nim współwystępują), a proporcjonalne wielopartyjny. Im więcej tego typu państw zidentyfikujemy, tym większe prawdopodobieństwo, że badana zależność nie jest przypadkowa i nie jest korelacją, ale może mieć charakter ściśle przyczynowy; 
2. jeśli można znaleźć przynajmniej dwa państwa, które różnią się co do istoty pod względem ustroju politycznego, kultury politycznej, liczby i charakteru podziałów socjopolitycznych, wielkości populacji itd., a nie różnią się pod względem formatu systemu partyjnego (dwupartyjny) i typu systemu wyborczego (większościowy), to znając naturę obydwu systemów, można wyciągnąć wniosek, że systemy większościowe determinują format dwupartyjny. Im więcej tego typu państw znajdziemy, tym większe prawdopodobieństwo, że badana zależność ma charakter przyczynowy.

Komparatystka dostarcza bardzo wielu informacji empirycznych, które można później z powodzeniem wykorzystać do konstruowania - drogą indukcji - nieobciążonych wartościowaniem teorii (Antoszewski, 2000, s. 153-154). Mimo wyodrębniania przez niektórych badaczy „polityki porównawczej” jako subdyscypliny współczesnej politologii, Jonathan Hopkin (2006, s. 251-252) trafnie zauważa, że metoda ta explicite lub implicite jest stosowana w całej politologii czy szerzej - nawet w naukach społecznych. Dzieje się tak dlatego, że metoda porównawcza stanowi najbardziej oczywistą drogę umożliwiającą testowanie twierdzeń teoretycznych na gruncie nauki o polityce. W przeciwieństwie do nauk przyrodniczych, gdzie podstawową formą kontroli prawdziwości twierdzeń teoretycznych jest powtarzalność uzyskiwanych wyników, w politologii nie jest to takie proste. Niemal nigdy nie da się bowiem stworzyć warunków laboratoryjnych umożliwiających przetestowanie teorii. Brak możliwości kontrolowania wszystkich aspektów badanej rzeczywistości powoduje, że politolodzy muszą zadowolić się metodą porównawczą, umiejętnie i kreatywnie wykorzystując dostępne im obserwacje świata politycznego. Zdaniem polskiego politologa Andrzeja Antoszewskiego (1997, s. 37) analiza powiązań między typem reżimu politycznego, systemem reprezentacji interesów, strategiami politycznymi, poziomem stabilności politycznej jest de facto możliwa tylko przy wykorzystaniu metody porównawczej. Stosowanie tego podejścia umożliwia formułowanie teoretycznych uogólnień wynikających $\mathrm{z}$ analizy materiału empirycznego i jest dużo bardziej wartościowe naukowo niż dominujący jeszcze nie tak dawno w badaniach deskryptywizm. Ilościowo zorientowana komparatystyka jest szczególnie przydatna przy analizie systemów partyjnych, relewancji partii politycznych oraz badaniu systemów i zachowań wyborczych.

Nie ulega wątpliwości, że komparatystyka jest najważniejszym, najpopularniejszym i najbardziej wartościowym poznawczo podejściem metodologicznym w obszarze studiów wyborczych. Przeglądając jednak konkretne wyniki badań, można zauważyć, że pod pojęciem „metoda porównawcza” kryją się różne spo- 
soby zbierania i analizowania danych, odmienne są też szczegółowe techniki badawcze. Co więcej, w literaturze przedmiotu panuje duże zróżnicowanie związane z pojmowaniem takich terminów jak „komparatystyka” czy „metoda porównawcza”. Nie wszyscy badacze zgadzają się z rozumieniem komparatystyki jako konkretnej metody, mówiąc raczej w tym przypadku o podejściu, strategii badawczej, „wygodnym terminie” niejasno symbolizującym, na czym skupia się uwaga danego badacza, czy wręcz, jak w przypadku Harolda Lasswella, na utożsamieniu komparatystyki z podejściem naukowym do badania polityki w ogóle (Lijphart, 1971, s. 682).

W tym kontekście zasadne wydaje się rozważenie, czy zamiast o metodzie porównawczej (w liczbie pojedynczej) nie powinniśmy raczej mówić o metodach (w liczbie mnogiej) lub ewentualnie grupie metod porównawczych, a może nawet o paradygmacie porównawczym? Jak się bowiem okazuje w praktyce, samo stwierdzenie, że badanie ma charakter porównawczy, niewiele nam mówi o jego specyfice i założeniach metodologicznych ${ }^{2}$. Znajdowanie podobieństw i różnic wśród badanych obiektów, następnie przeprowadzanie ich typizacji oraz generalizowanie na temat powstałych w ten sposób kategorii jawi się jako oczywista ścieżka metodologiczna. Badacz, który poprzestaje na stwierdzeniu, że zastosował w swoich badaniach metodę porównawczą, nie mówi nam więc nic o szczegółach swojej metodologii. Przykładowo Roman Tokarczyk (2005) wymienia, aż 10 różnych metod wykorzystywanych w komparatystyce prawniczej ${ }^{3}$. W rezultacie porównanie porównaniu nie jest równe. Dlatego w mojej opinii nie należy mówić o metodzie porównawczej, tak jak zresztą nie mówi się o metodzie ilościowej, tylko o grupie metod porównawczych, tożsamych w podejściu do analizowanych obiektów, ale różnych w sposobie ich ujmowania i porównywania. Poniżej zaprezentowane zostaną najważniejsze z nich.

\footnotetext{
${ }^{2}$ Oczywiście poza tymi, które w świetle tego, co zostało już napisane wcześniej, są rudymentarne dla każdej komparatystyki politycznej.

${ }^{3} \mathrm{~W}$ ramach wyróżnionej przez tego autora grupy metod ogólnych wymienia on metody: dialektyczną, kontekstową, historyczno-opisową, etnologiczno-porównawczą i eksperymentalną. Z kolei wśród metod szczegółowych są to: formalno-dogmatyczna (tekstowa, funkcjonalna, logiczna, strukturalna (instytucjonalna) i statystyczna (zob. Tokarczyk, 2005, s. 189 i nast.).
} 


\section{METODA INSTYTUCJONALNA-PRAWNA}

Ujęcie to jest bardzo charakterystyczne dla tradycyjnie zorientowanego instytucjonalizmu przywiązującego dużą wagę do oficjalnych i formalnych reguł. Zastosowanie tej metody pozwala rozpoznać instytucjonalno-prawny aspekt badanej rzeczywistości politycznej uwypuklony w formalnych przejawach funkcjonowania systemu politycznego i jego podsystemów, przede wszystkim właśnie takich jak system wyborczy czy partyjny. Przedmiotem analizy w tym przypadku są teksty aktów normatywnych (Żebrowski, 2012, s. 32-32). Metoda ta dąży do ujmowania jednostek prawnych, norm, instytucji, systemów, rodzin, typów jako określonych struktur, wyróżniających się sobie tylko właściwą budową wewnętrzną (Tokarczyk, 2005, s. 195). Genetycznie jest to „stary” instytucjonalizm, który w warstwie epistemologicznej charakteryzuje się orientacją: strukturalistyczną (zakładającą, że struktury polityczne determinują zachowania społeczne), legalistyczną (prawo odgrywa kluczową rolę w funkcjonowaniu instytucji politycznych, dlatego musi być badane ze szczególną uwagą), holistyczną (ogniskującą się na systemach jako takich, a nie poszczególnych elementach, z jakich się te systemy składają), funkcjonalistyczną (obecność konkretnych instytucji jest niezbędna w państwach demokratycznych), normatywistyczną (skupiającą uwagę na „właściwym”, „dobrym” czy „prawidłowym” funkcjonowania instytucji). Instytucjonalizm, korzystając $z$ narzędzi badawczych prawnika i historyka, przedmiotem swoich badań czyni więc przede wszystkim reguły i procedury oraz formalny wymiar polityki (Lownds, 2006, s. 91).

W badaniach systemów wyborczych podejście takie reprezentowane jest głównie przez przedstawicieli nauk prawnych, którzy metodę tę - ze względu na jej założenia, w tym naturę badanych zjawisk - określają mianem „strukturalnej”. Przedmiotem stosowanej przez nich analizy instytucjonalno-prawnej są przepisy prawa wyborczego i dekodowane z nich normy (Pierzgalski, 2012, s. 64). W zależności od przyjętego rozumienia systemu wyborczego badany jest zbiór reguł prawnych odnoszących się do zasad, trybu i organizacji przeprowadzenia wyborów w danym państwie (w nomenklaturze prawniczej tzw. system wyborczy sensu largo) albo tylko do zasad głosowania i ustalania wyników (system wyborczy sensu stricto). Dodatkowo każde z tych pojęć analizować można, rozszerzając lub zawężając jego rozumienie. Posługując się terminologią zaproponowaną przez Arkadiusza Żukowskiego (2005, s. 278), można powiedzieć, że przedmiotem badania może być zarówno hardware (prawo wyborcze), jak i software (praktyka wyborcza) systemu wyborczego. Implikuje to oczywiście 
inny zbiór obiektów poddawanych analizie i inne narzędzia pomiaru. To, co jednak pozostaje wspólne dla tego podejścia, to badanie różnych aspektów prawa wyborczego w celu zidentyfikowania charakterystyki instytucjonalnej systemu wyborczego (analizy konkretnych rozwiązań prawno-politycznych), a więc raczej odpowiedzi na pytanie ,jak jest zbudowany dany system wyborczy?”, ewentualnie „Czy jego instytucjonalny kształt jest adekwatny do modelu ustrojowego danego państwa?” niż „jakie konkretnie wywołuje konsekwencje polityczne?”.

Najprostszą techniką badawczą w obrębie tej metody jest podejście określane mianem case study, czyli studium konkretnego przypadku. Jednostką analizy jest w tym przypadku konkretne państwo, a precyzyjniej rzecz ujmując, jego system wyborczy, który traktowany jest jako zespół reguł umożliwiających przeprowadzenie wyborów na danym obszarze. Oczywiście ograniczenie analizy tylko i wyłącznie do konkretnego systemu wyborczego jednego państwa nie daje możliwości zastosowania procedury porównawczej. W konsekwencji uniemożliwia to sformułowanie jakichkolwiek generalizacji, sprowadzając samo badanie jedynie do elementu prostej deskrypcji ${ }^{4}$. Tymczasem działanie poszczególnych systemów wyborczych może zostać zrozumiane i poddane ewaluacji tylko w porównaniu z innymi systemami (Taagepera, Shugart, 1989, s. 61). Dlatego by zachować porównawczy charakter analizy instytucjonalnej takiego studium, należy rozszerzyć zakres jego badania w czasie, tak by możliwe stało się uchwycenie zmian w obrębie badanego systemu, a co za tym idzie - kierunku i konsekwencji jego ewolucji. Wtedy przedmiotem analizy przestaje być jednak państwo, a stają się nim kolejne reformy i zmiany prawa wyborczego danego $\mathrm{kraju}^{5}$. Celem tego typu badań jest zrekonstruowanie pewnego modelu systemu czy prawa wyborczego obowiązującego w danym państwie oraz ocena jego zgodności z normatywnie przyjętym wzorcem, czy to w konstytucji danego państwa, jego historii, praktyce ustrojowej, czy też poglądach teoretyków doktryny.

${ }^{4}$ Jakkolwiek zdaniem Lijpharta (1971, s. 691-692) studium pojedynczego przypadku, naukowo dwuznaczne ze względu na niemożliwość sformułowania jakichkolwiek generalizacji (a to jest wszak celem nauki), jest mimo wszystko wartościowe poznawczo i to nie tylko dlatego, że daje możliwość dogłębnego przebadania danego obiektu. Może bowiem wnieść także ważny wkład w procesie wypracowywania i ulepszania propozycji teoretycznych jako dostarczyciel „budulca” dla teorii. Wkład ten może przybrać postać kluczowych danych wejściowych, propozycji pewnych hipotez albo potwierdzonych już tym przypadkiem twierdzeń wartych przetestowania na większej liczbie obiektów. W tym sensie studia konkretnych przypadków mogą stać się ważnym elementem czy etapem w ramach szerszych badań porównawczych.

${ }^{5}$ Przykładem tego typu badań są m.in. prace takich specjalistów od polskiego prawa wyborczego jak: J. Buczkowski (1998), K. Skotnicki (2000), A. Sokala (2010). 
W badaniach porównawczych należy zawsze dążyć do zwiększania liczby analizowanych obiektów. Nie jest jednak metodologicznym wymogiem tego podejścia objęcie zakresem badania wszystkich wariantów danego rozwiązania występujących na świecie. Zazwyczaj badacz korzystający z metody instytucjonalno-prawnej ogranicza się do analizy tych państw, których regulacje są typowe dla interesujących go instytucji prawnych, a więc konstruują pewien model wyborczy możliwy do naśladowania i z tego powodu powielany przez wiele innych państw. Ewentualnie badane mogą być również państwa o rozwiązaniach oryginalnych, mogących stanowić inspirację dla rozwoju danej instytucji czy systemu w przyszłości, lub przeciwnie, przykłady antywzorca będącego wyrazem zaprzeczenia lub degeneracji idei w nim pierwotnie zawartej.

Zestawienie ze sobą rozwiązań wielu państw - studia wielu przypadków - pozwala już na przeprowadzenie szerokich porównań. Nadal jednak dominującym paradygmatem jest perspektywa instytucjonalna. Oznacza to, że porównywane są konkretne instytucje, rozwiązania prawne czy nawet całe systemy. Zidentyfikowanie podobieństw i/lub różnic instytucjonalnych umożliwia uporządkowanie obiektów, najczęściej w oparciu o jedno kryterium wiodące. W badaniach systemów wyborczych takim kryterium bardzo często jest formuła wyborcza. Efektem tak przeprowadzonych badań porównawczych jest opis i analiza rozwiązań prawnych w obrębie badanych państw, całych systemów ${ }^{6}$ lub jedynie pewnych wyodrębnionych przez badacza elementów prawa czy systemów wyborczych ${ }^{7}$.

Reasumując, metoda instytucjonalno-prawna charakteryzuje się tym, że:

1. przedmiotem badań czyni przede wszystkich oficjalne instytucje i struktury życia politycznego;

2. badania są nastawione na zidentyfikowanie celów i funkcji realizowanych przez te instytucje w społeczeństwie, raczej mechanizmów i prawidłowości działania tych struktur niż wykrywanie regularnie generowanych za ich przyczyną konsekwencji;

3. podstawowym materiałem źródłowym są przepisy prawa i ewentualnie praktyka ich stosowania;

4. dużą wagę przywiązuje się do deskrypcji;

\footnotetext{
6 Tytułem przykładu wymienić można opracowanie S. Grabowskiej i K. Składowskiego (2006).

7 Przykładem praca P. Uziębło (2013).
} 
5. zakres badań obejmuje studium konkretnego przypadku $(1 N)$ lub komparatystykę na małej liczbie $N$, obejmujących niewiele, za to z rozmysłem wybranych przypadków badawczych;

6. silnym naciskiem na warstwę normatywną związaną z oceną zastosowanych rozwiązań w zakresie ich prawidłowości, zgodności, optymalności oraz użyteczności z przyjętymi przez badacza wzorcami ewaluacyjnymi.

\section{METODA HISTORYCZNO-EMPIRYCZNA}

Nazwa i konceptualizacja kolejnego podejścia pochodzi od niemieckiego badacza systemów wyborczych Dietera Nohlena (2004, s. 158-160). Opisywana przez niego metoda opiera się na próbie rozróżnienia systemów wyborczych według określonych typów, na niższym poziomie analizy niż elementarny podział systemów wyborczych według charakteru ich formuły. Grupowanie badanych przypadków, jakie w tej procedurze należy wykonać, pozwala rozwiązać problem dużej liczby empirycznie występujących systemów wyborczych. Kwestia oceny systemów wyborczych skupia się na tych typach, których skutki można formułować w sposób abstrakcyjny, nie odchodząc przy tym daleko od rzeczywistości politycznej. Systemy wyborcze typizowane według bardziej szczegółowego podziału niż proporcjonalne i większościowe dają się już opisać w kategoriach generowanych przez nie efektów. W tym przypadku kwestie techniczne systemów wyborczych rozpatruje się o tyle, o ile mają one istotne znaczenie dla klasyfikacji.

Badanie systemów wyborczych przy wykorzystaniu metody historyczno-empirycznej wymaga spojrzenia ponad normatywno-instytucjonalny wymiar danego systemu. Ważne jest tu także tło historyczne i polityczne. Ponieważ skutki systemów wyborczych są zależne od czynników kontekstowych, ich ocena wymaga brania pod uwagę doświadczeń związanych z czasem, miejscem i historią badanego systemu (Nohlen, 2004, s. 143). Charakter i poziom szczegółowości tych informacji jest jednak ściśle zdeterminowany i podporządkowany zakresowi badania. Badacza interesują bowiem przede wszystkim cele i efekty polityczne generowane przez te systemy. Wymaga to zastosowania zróżnicowanych narzędzi analizy. Punktem wyjścia jest oczywiście analiza instytucjonalna, choć źródłem dla niej nie muszą być w tym przypadku koniecznie przepisy prawa. Wystarczy, że zestaw danych wejściowych pozwala na poprawne zidentyfikowanie kluczowych z punktu widzenia swoich konsekwencji cech badanych systemów. Sama analiza norm prawnych nie jest celem naukowców stosujących tę metodologię, 
a jedynie środkiem do realizacji celu, jakim jest uzyskanie adekwatnego opisu mechanizmu wyborczego. $Z$ tego też powodu badacze stosujący tę metodę często korzystają z już wcześniej przeprowadzonych analiz tego typu. Robią to, aby nie musieć przedzierać się przez gąszcz przepisów w celu dotarcia do potrzebnych im informacji.

Państwo, a dokładnie rzecz ujmując, jego system wyborczy, nadal pozostaje przedmiotem analizy, jednak w przeciwieństwie do metody instytucjonalno-prawnej podejście historyczno-empiryczne zaleca prowadzenie badań na większej liczbie przypadków. Wychodzi się tu bowiem z założenia, że działanie partykularnego systemu może być zrozumiane i ocenione tylko w porównaniu z innymi systemami, a praktyka jednego przypadku niewiele mówi na temat możliwości pozostałych. Dlatego następnym etapem jest opisanie i sklasyfikowanie występujących na świecie systemów wyborczych w sposób zwięzły, a jednocześnie zadowalający w szczegółach (Taagepera, Shugart, 1989, s. 61). Dąży się więc do zredukowania liczby badanych przypadków, nie poprzez ich skrupulatne wyselekcjonowanie spośród wszystkich empirycznie dostępnych (tak jak w metodzie instytucjonalno-prawnej), ale analityczne zamknięcie w obrębie określonej typologii. Typologia ta musi mieć jednak duży związek z empirią. Nohlen (2004, s. 162) nazywa to średnim poziomem analizy (poziomem typów systemów wyborczych), występującym pomiędzy najwyższym poziomem, reprezentowanym przez dychotomię: systemy większościowe vs. proporcjonalnie, a najniższym, czyli konkretnych systemów wyborczych funkcjonujących w poszczególnych państwach. Dzięki temu można przyporządkować każde państwo do względnie niedużej, ale skonkretyzowanej przez swoje rozwiązania i przede wszystkim efekty polityczne, grupy. Generalizacje powinny być budowane w odniesieniu do zidentyfikowanych typów systemów wyborczych, a niereprezentujących je państw. Typizacji podlegają z kolei całe systemy wraz ze swoją historyczną ewolucją, a nie ich historycznie czy technicznie wyodrębnione fragmenty.

W praktyce podejście historyczno-empiryczne jest najszerzej rozpowszechnioną metodą badania systemów wyborczych na gruncie politologii. Dzięki niej nastąpił duży przyrost wiedzy na temat funkcjonowania i konsekwencji politycznych systemów wyborczych. Metoda ta przyczyniła się również, ze względu na konieczność posługiwania się klasyfikacjami w procedurze badawczej, do wypracowania wielu użytecznych typologii systemów wyborczych. Tym samym odeszła od coraz mniej istotnego poznawczo dychotomizowania systemów wyborczych na większościowe i proporcjonalne. $\mathrm{W}$ istocie wiele kluczowych 
badań dla studiów wyborczych posługiwało się - bardziej czy mniej świadomie - właśnie tym metodologicznym instrumentarium ${ }^{8}$.

Podsumowując, do najważniejszych cech charakterystycznych tej metody można zaliczyć:

1. jakościową, ewentualnie jakościowo-ilościową, perspektywę porównawczą;

2. przeniesienie uwagi badawczej ze struktury systemu wyborczego na jego efekty, jednak z uwzględnieniem szerszego kontekstu, np. społecznego, politycznego, historycznego i geograficznego;

3. poszukiwanie istotnych kryteriów różnicujących systemy wyborcze, zarówno na płaszczyźnie rozwiązań technicznych, generowanych przez nie konsekwencji politycznych, jak i środowiska, w jakim funkcjonują;

4. zbudowanie niezbyt wyabstrahowanej typologii pozwalającej na uporządkowanie i zredukowanie liczby wszystkich empirycznie występujących (tak w przeszłości, jak i obecnie) systemów wyborczych;

5. sformułowanie generalizacji na temat właściwości tak wyróżnionych typów systemów wyborczych.

\section{METODA EMPIRYCZNO-STATYSTYCZNA}

Kolejne podejście badawcze zorientowane jest na analizę konkretnych zmiennych technicznych wpływających na skutki polityczne w obrębie przede wszystkim systemu partyjnego ${ }^{9}$. W metodzie historyczno-empirycznej chodziło o zredukowanie liczby badanych przypadków przez „zamknięcie” ich w obrębie adekwatnej typologii. Tymczasem w metodzie empiryczno-statystycznej cel jest dokładnie odwrotny. Problemem nie jest wcale zbyt duża różnorodność w świecie systemów wyborczych, ale często ograniczony zbiór danych empirycznych na wejściu. Celem tego podejścia jest operowania na jak największej liczbie przypadków, czasami nawet sztucznie zwiększanej ${ }^{10}$. Różne kombinacje elementów technicznych

${ }^{8}$ Można w tym kontekście wymienić prace takich klasyków studiów wyborczych jak chociażby: M. Duverger (1954), R. Katz (1980), M.S. Shugart, M.P. Wattenberg (2001), D. Nohlen (2004), M. Gallagher, P. Mitchell (2005).

9 Nohlen (2004, s. 158) nazywa to podejściem empiryczno-statystycznym, podczas gdy Lijphart (1971, s. 684) określa je po prostu mianem metody statystycznej.

10 Tak postąpił np. Lijphart (1994), wybierając jako jednostkę analizy nie pojedynczą elekcję, jak to było praktykowane od czasu Douglasa Rae (1971, s. 69 i n.), pioniera wyborczych badań porównawczych, który dokładnie z tego samego powodu zrezygnował z posługiwania się oczywistą $\mathrm{w}$ tamtych czasach kategorią państwa, ale system wyborczy rozumiany jako zbiór niezmiennych reguł 
systemów wyborczych pozwalają zwiększyć liczbę przypadków, dzięki czemu powstają lepsze warunki dla skutecznego zastosowania tej metody (Nohlen, 2004, s. 158). Jak zauważa Lijphart (1971, s. 684), podejście to jest całkowicie zbieżne z klasyczną metodą porównawczą, z jednym wyjątkiem: liczby badanych przypadków. W badaniach przeprowadzonych tradycyjną metodą porównawczą (oczywiście pod warunkiem, że jest ona zorientowana ilościowo) liczba analizowanych obiektów jest zbyt mała, aby umożliwić systematyczną kontrolę za pomocą cząstkowych korelacji ${ }^{11}$. W konsekwencji nie ma wyraźnej linii rozgraniczającej obydwie metody. Różnica zależy tylko od liczby rozpatrywanych przypadków.

Kwestia zbyt małej liczby przypadków, i jeszcze mniejszej liczby danych uzyskiwanych z tych przypadków, jest niezmiennym i największym problemem metody statystycznej (Hopkin, 2006, s. 260). Jest on tym bardziej dokuczliwy, gdy badacz stara się objąć kontrolą zbyt wiele różnych zmiennych naraz. Może to doprowadzić do szybkiego „wyczerpania się” przypadków ${ }^{12}$. Dlatego operowanie obserwowalnymi danymi empirycznymi - w przypadku studiów wyborczych będą to przede wszystkim głosy wyborców i mandaty partii politycznych musi być podporządkowane wykryciu relacji pomiędzy kontrolowaną, zwykle niewielką, ale podejrzewaną o relewantność, liczbą zmiennych (Lijphart, 1971, s. 684). Tymczasem wielu politologów umieszcza w swoich badaniach zbyt dużą liczbę zmiennych na wejściu i poddaje je prostej analizie regresji. Uzyskane w ten sposób zależności statystyczne nie mają ani charakteru liniowego, ani nie dostarczają ograniczonej liczby innych charakterystycznych wzorców. Ten sam badacz może zaprezentować wiele alternatywnych regresji, włączając bądź wyłączając niektóre zmienne. Są to raczej wyjaśnienia równoległe niż oczekiwane twierdzenia o charakterze sekwencji przyczynowo-skutkowych (Taagepera, 2007, s. VII). Dlatego stosując to podejście należy używać tylko kilku zmiennych jed-

wyborczych, pod rządami których przeprowadzone były kolejne elekcje. Zmiana pewnych elementów systemu wyborczego prowadziła do zmiany całego systemu i potraktowania go jako osobnej jednostki analizy.

${ }^{11}$ Badania tego rodzaju charakteryzuje mała próba. Uniemożliwia to przeprowadzenie pełnej analizy statystycznej uzyskanych wyników. Podejście to, ze względu na swoją kompleksowość i określony schemat porządkowania, przetwarzania i interpretowania danych, nazywa się czasami metodą (analizą) indeksową (zob. Michalak, 2012). Faktycznie jest to jednak tylko jedno z możliwych do wykorzystania szczegółowych podejść komparatystycznych.

${ }^{12}$ D. Mider i A. Marcinkowska (2013, s. 48), powołując się na literaturę przedmiotu, podają, że minimalna ilość przypadków niezbędna, aby można było formułować jakieś uogólnienia i przenosić je z próby na populację, wynosi 30 lub nawet 120 jednostek analizy. 
nocześnie, połączonych konkretnym związkiem, który zamierzamy przetestować przy wykorzystaniu dostępnych w statystyce technik i narzędzi. Jednak również w tym przypadku istnieje poważne niebezpieczeństwo związane, po pierwsze, z błędami pomiaru i niedokładnością danych wejściowych, po drugie, z doborem nieodpowiednich wskaźników dla zmiennych empirycznych. Pogoń za łatwo poddającymi się analizom statystycznym danymi liczbowymi może prowadzić do wyboru danych niekoniecznie ściśle związanych z badanym problemem. Jeśli wybrany do analizy wskaźnik nie mierzy zmiennej, której ma dotyczyć, wyniki całego badania siłą rzeczy stają się niewiarygodne (Hopkin, 2006, s. 260).

Podejście ilościowe jest jednak dla tej metody bardzo charakterystyczne i ważne. Celem większości ilościowych analiz porównawczych jest ocena związków pomiędzy zmiennymi na podstawie dużej liczby przypadków przy pomocy różnych technik statystycznych. Kontekst jest tutaj nie tyle kontrolowany, co pomijany. Jeśli bowiem założony pomiędzy analizowanymi zmiennymi związek istnieje w dostatecznie wielu różnych kontekstach, to znaczy, że nie odgrywa on żadnego znaczenia ${ }^{13}$. Wymaga to więc operowania na danych liczbowych lub zmiennych łatwo poddających się takiej kwantyfikacji (Hopkin, 2006, s. 258). $\mathrm{Z}$ tego powodu problemy i pytania formułowane w ilościowo zorientowanych badaniach koncentrują się na częstości występowania określonych zjawisk w badanej grupie, ilościowo zdefiniowanych relacjach badanych zjawisk, zależnościach pomiędzy zmiennymi oraz różnicach między badanymi grupami pod względem ilościowym (Mider, Marcinkowska, 2013, s. 48). Liczba głosów, mandatów, partii politycznych, utworzonych koalicji i gabinetów doskonale nadają się do takich właśnie analiz.

Metodę empiryczno-statystyczną na gruncie studiów wyborczych jako pierwszy wykorzystał na szeroką skalę Douglas Rae (1971), dokonując kompleksowej komparatystyki systemów wyborczych przy użyciu szeregu wskaźników empirycznych, w tym wielu opracowanych przez siebie indeksów matematycznych, takich chociażby jak indeks frakcjonalizacji czy dwupartyjnej koncentracji ${ }^{14}$, by następnie poddać je obróbce przy wykorzystaniu narzędzi charakterystycznych dla statystyki opisowej. Ten sposób analizy stał się ważnym stymulatorem dla podejmowania następnych projektów naukowych, a same badania wkrótce

${ }^{13}$ Widać tutaj logikę charakterystyczną dla komparatystyki opartej na metodzie różnicy.

14 Rae (1971, s. 16-17) wyodrębnił trzy kluczowe parametry techniczne systemów wyborczych, które następnie poddał analizie z punktu widzenia wywieranych przez nie konsekwencji politycznych. Były to: formuła wyborcza, wielkość okręgów wyborczych oraz struktura głosu wyborcy. 
urosły do rangi klasycznych. Metoda ta szybo zyskała wielu naśladowców. Jej najwybitniejszy przedstawiciel - Arend Lijphart (1994) - nie tylko z powodzeniem kontynuował analizę zaproponowaną przez poprzednika, ale ją udoskonalił, przez co zyskała ona status kompleksowej metody badawczej ${ }^{15}$. By zminimalizować ryzyko sformułowania przedwczesnych generalizacji, bo wyprowadzonych na podstawie zbyt małej liczby przypadków, jako jednostkę analizy Lijphart przyjął nie tylko pojedynczą elekcję (jak to uczynił Rae), ale również konkretny, narodowy system wyborczy. Poza tym, że w ten sposób zwiększył liczbę badanych obiektów empirycznych, mógł dzięki temu prostemu zabiegowi metodologicznemu zarejestrować, w jaki sposób zmiana systemu wyborczego w danym państwie przekłada się na zmianę w obszarze generowanych przez ten system konsekwencji politycznych. Mając kontrolę nad momentem zmiany systemu wyborczego, można bowiem z jeszcze większą ufnością podchodzić do efektów politycznych danej elekcji. Zaadaptowanie tej metody miało uwrażliwić wyniki badania na ryzyko zniekształceń wywołanych przez nadreprezentację stabilniejszych systemów wyborczych, które na skutek swojej „długowieczności” wyprodukowały więcej elekcji. Z tego też powodu metodologia i rezultaty badawcze uzyskane przez holenderskiego politologa przez wielu uczonych uznawane są za szczytowe osiągnięcie subdyscypliny w wymiarze makro. Niektórzy, jak Shugart (2005, s. 27-31), twierdzą nawet, że wzrost badań odwołujących się do podejścia statystycznego świadczy o osiągnięciu dojrzałości badawczej całej dyscypliny. W istocie jedna $\mathrm{z}$ podstawowych statystycznych technik, jaką jest analiza regresji, jest w tej chwili głównym narzędziem badawczym w całej zachodniej politologii porównawczej (Taagepera, 2007, s. VII).

Niewątpliwie statystyczno-empiryczne analizy odgrywają obecnie centralną rolę w badaniach nad systemami wyborczymi. Metoda ta jednak często nie rozwiązuje problemów konceptualnych, podporządkowując rozumienie ważnych kategorii teoretycznych wymogom lepszej kwantyfikacji problemu badawczego. To wszystko prowadzi do nadmiernego redukcjonizmu, przenosząc uwagę z systemu wyborczego jako całość na jego specyficzne, przede wszystkim zaś techniczne aspekty. Skutkuje to zignorowaniem kontekstu, w jakim działa dany system wyborczy (Nohlen, 2010, s. 50-52).

${ }^{15} \mathrm{Z}$ metody empiryczno-statystycznej, choć nie zawsze tylko z niej, w badaniach systemów wyborczych z powodzeniem korzystali m.in.: R. Taagepera, M. Shugart (1989), G. Cox (1997), D. Farrell (2001), P. Norris (2004), F. Ferrara, E.S. Heron, M. Nishikawa (2005). 
Podsumowując, do najważniejszych cech charakterystycznych tej metody można zaliczyć:

1. ilościowo-komparatystyczną perspektywę, pomijającą kontekst (społeczny, polityczny, geograficzny i historyczny) badanych systemów;

2. operowanie na jak największej liczbie przypadków (duże $N$ );

3. stosowanie na szeroką skalę analizy wskaźnikowej i statystycznej;

4. przeniesienie uwagi badawczej z systemu wyborczego jako całości na jego poszczególne elementy;

5. ukierunkowanie na poszukiwanie statystycznie istotnych zależności pomiędzy konkretnymi elementami technicznymi systemów wyborczych (zmienne niezależne) a generowanymi przez nie efektami (zmienne zależne), przede wszystkim w obszarze dysproporcjonalności wyników wyborów, struktury systemów partyjnych oraz zachowań wyborczych elektoratu.

\section{METODA LOGICZNO-EMPIRYCZNA}

Fizyk i zarazem politolog estońskiego pochodzenia Rein Taagepera (2008) jest autorem bardzo ciekawej i dopiero co zdobywającej popularność metody badania systemów wyborczych.W jego ocenie tradycyjne podejście statystyczne jest zasadniczo deskryptywne (opis przy pomocy słów zastępuje opis za pomocą liczb) i nie spełnia predykcyjnej funkcji w nauce. Współcześni badacze pozostają pod przemożną presją zastosowania prostych technik statystycznych (jak regresja liniowa) do analizy wszelkich dających się skwantyfikować problemów. Tymczasem w naukach społecznych analiza danych statystycznych jest często przeceniana, a predykcyjny cel badania ograniczany jedynie do wskazania kierunku oddziaływania badanego efektu, pozostawiając badaczy w niewiedzy co do jego faktycznego poziomu ilościowego. Remedium na ograniczenia tradycyjnej statystyki ma być - zdaniem tego autora - wykorzystanie logiczno-empirycznych modeli predykcyjnych (Quantitatively Predictive Logical Models). Proponowana przez niego metoda łączy w sobie wnioskowanie dedukcyjne (logiczny aspekt tej metody) z indukcyjnym (aspekt empiryczno-ilościowy), umożliwiając formułowanie przydatnych w praktyce predykcji (przewidywań). Wbrew pozorom nie pociąga to za sobą konieczności przeprowadzania bardziej skomplikowanych analiz matematyczno-statystycznych niż np. analiza regresji. Wymaga natomiast dobrego przemyślenia logicznych związków, jakie zachodzą pomiędzy badanymi zmiennymi. 
Jak konstruować takie modele? Przede wszystkim zgodnie z zasadą „brzytwy Ockhama”. Powinny być tak proste, jak to tylko możliwe, i nie prowadzić do absurdalnych wniosków nawet w ekstremalnych okolicznościach. Drogą eliminacji należy odrzucić wszystkie relacje, które nie mogą logicznie wystąpić, tak długo, aż zostanie nam kilka (najlepiej tylko jedna) możliwości wyjaśnienia danej relacji. Podejście to kładzie więc duży nacisk na właściwe zdefiniowanie związków zachodzących pomiędzy analizowanymi zmiennymi. Ponieważ w naukach społecznych wiele zmiennych ma raczej charakter współzależny niż zależny czy niezależny, lepiej jest mówić w tym przypadku o zmiennych wejściowych i wyjściowych danego badania (Taagepera, 2008, s. 23, 29).

By lepiej zrozumieć opisywaną metodę, przeanalizujmy prosty przykład podany przez samego autora (zob. Taagepera, 2007, s. 118 i n.), dotyczący przewidywanej liczby partii politycznych, które mogą zdobyć co najmniej jeden mandat $\mathrm{w}$ danym okręgu wyborczym. Załóżmy więc, że mamy do czynienia z okręgiem 100-mandatowym. Oczywiście nie mając żadnych innych informacji na temat rywalizujących w wyborach partii politycznych, musimy zgadywać co do ich liczby. Żeby maksymalnie zminimalizować wielkość błędu, możemy skorzystać właśnie z metody logiczno-empirycznej. Analizę powinniśmy zacząć od wyznaczenia przewidywanych wartości ekstremalnych. Na jednym końcu będziemy mieli sytuację, w której partia zdobywa wszystkie mandaty, a na drugim po jednym mandacie uzyskuje sto różnych podmiotów. Tak więc zgodnie z zasadami logiki teoretyczna liczba partii politycznych mogących uzyskać co najmniej jeden mandat w okręgu będzie zawierać się w przedziale od 1 do 100. W warunkach demokratycznych obydwie wartości są skrajnie nieprawdopodobne. Są jednak teoretycznie możliwe, dlatego Taagepera nazywa ten zakres konceptualnie możliwym. Jest to tylko punkt wyjścia do dalszych analiz. Jednak już na tym etapie wiemy, że partii takich musi być co najmniej 1 i nie będzie ich więcej niż 100. Zakres ten jest oczywiście zdecydowanie za szeroki, by mógł być praktycznie przydatny. Nie jesteśmy jednak bezsilni i w tej sytuacji możemy posłużyć się średnią, która pozwoli nam dalej zredukować liczbę hipotetycznych możliwości. Średnia arytmetyczna w tym przypadku nadal będzie zbyt duża, bo wyniesie 50,5 partii. Podobnie liczba mandatów przypadająca na jedną partię może wahać się od 1-100, a więc średnia wyniesie również 50,5. Obydwie wartości rozpatrywane razem prowadzą więc do logicznej niemożliwości, a tego nie dopuszczają założenia metodologiczne tej metody. Aby spełnić obydwa warunki równocześnie, parlament musiałby w tym przypadku liczyć 2550 mandatów (50,5 $x 50,5)$. Jest to oczywiście wartość pozostająca poza empirycznie możliwym 
zakresem. By uniknąć tego paradoksu, należy posłużyć się średnią, ale geometryczną. Jej wykorzystanie pozwoli oszacować interesującą liczbę bardziej realnie. $\mathrm{W}$ tym wypadku będzie to 10 partii ${ }^{16}$. Dzięki temu możliwe jest formułowanie bardziej generalnych wniosków na temat liczby partii zdobywających (średnio) mandaty w okręgach wyborczych funkcjonujących w tzw. prostych systemach wyborczych ${ }^{17}$.

Uzyskany w ten sposób wynik może być dyskusyjny, ale prawda jest taka, że w sytuacji braku dostępu do jakichkolwiek dodatkowych informacji jest on lepszy niż żaden. Nic zresztą nie stoi na przeszkodzie, aby model ten dalej precyzować przez wprowadzenie do niego dodatkowych informacji. Dane te możemy pozyskać np. na drodze empirycznej, przez uśrednienie pomiaru jak największej liczby przypadków (Taagepera, 2007, s. 120-121). Można też wykorzystać dane i/lub trendy historyczne danego państwa. Dla przykładu, poszukując modelu przewidującego relację pomiędzy efektywną liczba partii parlamentarnych i efektywną liczbą partii wyborczych, Taagepera i Shugart (1989, s. 84-85), posługując się z jednej strony prostą analizą logiczną, a z drugiej strony medianą efektywnej liczby partii wyliczoną dla dużej liczby empirycznych przypadków, zaproponowali model pozwalający oszacować efektywną liczbę partii parlamentarnych $(N s)$ na podstawie danej wartości efektywnej liczby partii wyborczych $(N v)$ i na odwrót $^{18}$.

Reasumując, zaproponowana przez Taageperę metoda logiczno-empiryczna:

1. skupia się na funkcji predykcyjnej raczej niż eksplanacyjnej;

2. do analizy wybiera tylko kilka, dobrze uzasadnionych teoretycznie i/lub intuicyjnie, zmiennych, a następnie bada zachodzące pomiędzy nimi relacje;

${ }^{16} \mathrm{Z}$ tego powodu Taagepera (2008, s. 120 i n.) zaleca posługiwanie się średnią geometryczną we wszystkich możliwych sytuacjach, gdyż oferuje ona wyniki najbardziej zbliżone do wartości środkowej (mediany) poszukiwanej zmiennej, w przeciwieństwie do średniej arytmetycznej, która jest zbyt wrażliwa na wartości ekstremalne.

17 Taagepera (2007, s. 20) zalicza do nich klasyczny system większości względnej oraz proporcjonalnej reprezentacji zbudowany na listach partyjnych, dużych i niezróżnicowanych okręgach wyborczych oraz niezawierający w sobie bardziej skomplikowanych mechanizmów redystrybucyjnych.

${ }_{18}$ Zgodnie z tym modelem: $N s=N v-0,4$, a więc $N v=N s+0,4$, gdzie 0,4 jest parametrem uzyskanym dzięki badaniom empirycznym na dużej liczbie przypadków. W samodzielnie napisanej i dużo później wydanej pracy Taagepera (2007, s. 54-55), posługując się analizami empirycznymi, jeszcze bardziej sprecyzował tę zależność. 
3. konstruując teoretyczny model opisujący zależności pomiędzy interesującymi zmiennymi, posługuje się zasadami logicznej dedukcji i empirycznej testowalności;

4. operuje na jak największej liczbie przypadków (duże $N$ ) i wykorzystuje techniki statystyczne.

\section{PODSUMOWANIE}

Systemy wyborcze mogą być badane na różne sposoby. W naukach politycznych czy szerzej - w całej humanistyce regułą jest stosowanie raczej metod jakościowych. Tymczasem wykorzystanie analiz ilościowych może okazać się bardzo przydatne poznawczo, a na gruncie badań systemów wyborczych wręcz nieodzowne. Analiza ilościowa wspomaga bowiem obiektywizację wyników badań, jak również ułatwia diagnozowanie i prognozowanie (Pierzgalaski, 2012, s. 63).

W artykule tym starałem się zaprezentować najważniejsze i najczęściej wykorzystywane metody porównawcze stosowane obecnie w badaniach nad systemami wyborczymi. Celem było usystematyzowanie różnych orientacji, podejść i technik w ramach czterech precyzyjnie wyodrębnionych i szczegółowo scharakteryzowanych metod badawczych. Przedstawione zostały najważniejsze założenia epistemologiczne każdej z tych metod, charakteryzujące je dyrektywy, stosowane procedury badawcze, wykorzystywane techniki pomiaru, sposoby interpretacji uzyskanych wyników, możliwe do eksploracji przy ich wykorzystaniu obszary problemowe, przykłady konkretnych badań oraz możliwości i ograniczenia w ich stosowaniu. Należy podkreślić, że przedmiotem rozważań były tylko i wyłącznie metody pozwalające na badanie struktury instytucjonalnej systemu wyborczego, wywoływanych przez niego efektów politycznych oraz zachowań wyborczych ${ }^{19}$. Poza obszarem omówienia pozostały zatem inne kwestie podejmowane w obrębie studiów wyborczych, jak: analiza procesów decyzyjnych czy celów i przetargów politycznych związanych z konstruowaniem i ustanawianiem systemu wyborczego ${ }^{20}$.

19 M.S. Shugart (2005, s. 28) badanie relacji między różnymi cechami a efektami systemów wyborczych (takich jak proporcjonalność, liczba partii itp.) określił mianem „rdzenia komparatystyki systemów wyborczych".

20 Problemy te badane są przy wykorzystaniu takich metod, jak: analiza systemowa, analiza decyzyjna czy teoria gier. 
Omawiane metody można podzielić na trzy grupy: jakościowe (zorientowane na dokładną analizę niewielu przypadków), ilościowe (zorientowane na analizę dużej liczby przypadków) i porównawcze (zorientowane na porównywanie między sobą badanych przypadków). Generalnie wszystkie metody (poza studium jednego przypadku) należy zaklasyfikować do grupy metod porównawczych. Metoda instytucjonalno-prawna może mieć tylko jakościowy charakter, podczas gdy metody emipryczno-statystyczna i logiczno-predykcyjna tylko ilościowe. Z kolei analiza historyczno-empiryczna może być zarówno jakościowa, jak i ilościowa.

Jak widać, w obrębie studiów wyborczych znaleźć można podejścia porównawcze znacząco różniące się tak pod względem liczby porównywanych obiektów (małe $N$ vs. duże $N$ ), charakteru jednostek analizy (państwo, elekcja, konkretny system wyborczy, grupa systemów wyborczych itd.), technik zbierania i przetwarzania danych empirycznych (analiza norm prawnych, matematyczno-wskaźnikowa, statystyczna, logiczno-ilościowa) oraz schematów ich interpretacji. Wszystko to ma niebagatelne konsekwencje dla charakteru uzyskiwanych na podstawie tych badań generalizacji. W rezultacie paradygmat porównawczy obejmuje swym zakresem wiele różnych, czasami nawet rudymentarnie odmiennych (jak np. instytucjonalno-prawne studia kilku przypadków w zestawieniu z technikami statystycznej analizy danych operującymi na bardzo dużej próbie) technik badawczych. Są one różne zarówno pod względem swoich założeń wyjściowych, procedury badawczej oraz sposobu interpretacji wyników. Dlatego wydaje się konieczne ich metodologiczne wyodrębnienie jako osobnych metod porównawczych.

\section{BiBLIOGRAFIA:}

Antoszewski, A. (2000). Komparatystyka polityczna. W: W. Sokół, M. Żmigrodzki (red.), Encyklopedia politologii. Tom 1. Teoria polityki (s. 153-154). Kraków: Kantor Wydawniczy Zakamycze.

Antoszewski, A. (1997). Modele demokracji przedstawicielskiej. W: A. Antoszewski, R. Herbut (red.), Demokracje zachodnioeuropejskie. Analiza porównawcza (s. 15-38). Wrocław: Wydawnictwo Uniwersytetu Wrocławskiego.

Buczkowski, J. (1998). Podstawowe zasady prawa wyborczego III Rzeczypospolitej. Lublin: Wydawnictwo UMCS.

Cox, G. (1997). Making Votes Count. Strategic Coordination in the World's Electoral Systems. Cambridge: Cambridge University Press.

Duverger, D. (1954). Political Parties. Their Organization and Activity in the Modern State. London: Methuen. 
Farrell, D. (2001). Electoral Systems. A Comparative Introduction. Basingstoke: Palgrave Macmillan.

Ferrara, F., Heron, E.S., Nishikawa, M. (2005). Mixed Electoral Systems: Contamination and Its Consequences. New York: Palgrave Macmillan.

Gallgher, M., Mitchel, P. (red.). (2005). The Politics of Electoral Systems. Oxford University Press: Oxford-New York.

Grabowska, S., Składowski, K. (red.). (2006). Prawo wyborcze do parlamentu w wybranych państwach europejskich. Kraków: Kantor Wydawniczy Zakamycze.

Hopkin, J. (2006). Metoda porównawcza. W: D. Marsh, G. Stoker (red.), Teorie i metody w naukach politycznych (s. 251-269 ). Kraków: Wydawnictwo Uniwersytetu Jagiellońskiego.

Katz, R. (1980). A Theory of Parties ane Electoral Systems. Baltimore: Johns Hopkins University Pres.

Lijphart, A. (1971). Comparative Politics and the Comparative Method. The American Political Science Review, 65(3), 682-693.

Lijphart, A. (1994). Electoral Systems and Party Systems. A Study of Twenty-Seven Democracies 1945-1990. Oxford: Oxford University Press.

Lownds, V. (2006). Instytucjonalizm. W: D. Marsh, G. Stoker (red.), Teorie i metody w naukach politycznych (s. 89-107). Kraków: Wydawnictwo Uniwersytetu Jagiellońskiego.

Michalak, B. (2012). Badanie zależności pomiędzy systemem wyborczym a systemem partyjnym przy wykorzystaniu metody indeksowej. Przypadek mieszanych systemów wyborczych w Rosji i na Ukrainie oraz proporcjonalnej reprezentacji w Polsce. Athenaeum. Polskie Studia Politologiczne, 36, 94-113.

Mider, D., Marcinkowska, A. (2013). Analiza danych ilościowych dla politologów. Praktyczne wprowadzenie z wykorzystaniem programu GNU PSPP. Warszawa: ACAD.

Nohlen, D. (2010). Elections and Electoral Systems. W: D. Nohlen, P. Stöver (red.), Elections in Europe. A Data Handbook (s.1-67). Baden-Baden: Nomos.

Nohlen, D. (2004). Prawo wyborcze i system partyjny. O teorii systemów wyborczych. Warszawa: Wydawnictwo Naukowe Scholar.

Norris, P. (2004). Electoral Engineering: Voting Rules and Political Behavior. Cambridge: Cambridge University Press.

Pierzgalski, M. (2012). Metody ilościowe w badaniu systemów wyborczych. Na przykładach z państw Azji Wschodniej. Łódź: Wydawnictwo Uniwersytetu Łódzkiego.

Rae, D. (1971). The Political Consequences of Electoral Laws. New Hale: Yale University Press.

Skotnicki, K. (2000). Zasada powszechności w prawie wyborczym. Zagadnienia teorii i praktyki. Łódź: Wydawnictwo Uniwersytetu Łódzkiego.

Sokala, A. (2010). Administracja wyborcza w obowiązującym prawie polskim. Struktura organizacyjna, charakter prawny, kompetencje. Toruń: Wydawnictwo „Dom Organizatora”. 
Shugart, M.S. (2005). Comparative Electoral Systems Research: The Maturation of a Field and New Challenges Ahead. W: M.S. Shugart, M.P. Wattenberg (red.), The Politics of Electoral Systems. Oxford-New York: Oxford University Press.

Shugart, M.S., Wattenberg, M.P. (red.). (2001). Mixed-Member Electoral Systems: The Best of Both Worlds? Oxford: Oxford University Press.

Taagepera, R. (2007). Predicting Party Sizes. The Logic of Simple Electoral Systems. Oxford-New York: Oxford University Press.

Taagepera, R. (2008). Making Social Sciences More Scientific: The Need for Predictive Models. Oxford-New York: Oxford University Press.

Taagapera, R., Shugart, M.S. (1989). Seats and Votes. The Effects and Determinants of Electoral Systems. New Haven \& London: Yale University Press.

Tokarczyk, R. (2005). Komparatystyka prawnicza. Kraków: Zakamycze.

Uziębło, P. (2013). Zasada równości wyborów parlamentarnych w państwach europejskich i południowoamerykańskich. Warszawa: Wolters Kluwer Polska SA.

Żebrowski, W. (2012). Badanie polityki. Ogniwa procesu badawczego na studiach politologicznych. Olsztyn: Instytut Nauk Politycznych Uniwersytetu Warmińsko-Mazurskiego w Olsztynie.

Żukowski, A. (2005). Wybory. W: S. Opara, D. Radziszewska-Szczepaniak, A. Żukowski (red.), Podstawowe kategorie polityki. Olsztyn: Instytut Nauk Politycznych Uniwersytetu Warmińsko-Mazurskiego w Olsztynie. 